\title{
Stanowiska
}

\section{Nowa Humanistyka: w poszukiwaniu granic}

Agata Bielik-Robson

TEKSTY DRUGIE 2017, NR 1, S. 146-162

DOI: $10.18318 /$ td.2017.1.12

Zbyt mało człowieczeństwa oddala nas od natury, lecz jeszcze więcej przybliża nas do niej na powrót.

Emmanuel Lévinas, Trudna wolność

Nowa Humanistyka to dziedzina wewnętrznie bardzo różnorodna, wyrastająca z różnych dyskursów filozoficznych, ale jest chyba jedna tendencja, która dominuje i zbiera ją w całość: to poszukiwanie nowych granic.

Tym razem jednak nie chodzi o to, by granice przekraczać: zasada oświecenia jako permanentnej transgresji, obowiązująca od Kanta do Foucaulta, nie ma już nad Nową Humanistyką władzy'. Teraz chodzi o rzecz dokładnie odwrotną: o znalezienie granic jako trwałych ograniczeń, które położyłyby kres nowoczesnej idei podmiotu jako instancji potencjalnie nieograniczonej,

1 Michel Foucault, parafrazując Kantowską definicję oświecenia jako permanentnego Wyjścia, wykłada je jako ciągły skok na granice i transgresyjną czujność; nowoczesność zdaniem Foucaulta to myśl źle czująca się w warunkach apriorycznego ograniczenia. Por. M. Foucault Czym jest oświecenie, w: Filozofia, historia, polityka. Wybór pism, przeł. D. Leszczyński, L. Rasiński, PWN, Warszawa 2000.

\section{Agata Bielik-}

-Robson - zamiesz-

kała w Warszawie

i Nottingham. Pracuje w Instytucie Filozofii

i Socjologii PAN oraz jako profesor Jewish Studies na Wydziale Teologii i Religioznawstwa w University of Nottingham. Zajmuje się filozofią podmiotu, teorią literatury oraz filozofią religii, ze szczególnym uwzględnieniem dziedzictwa żydowskiego. Obecnie pracuje nad nową książką pt. Another Finitude. Religion of the Finite Life in Freud, Rosenzweig, and Derrida. Kontakt: abielik@ifispan. waw.pl 
uwalniającej się od każdej danej i przekraczającej każdy stan narzucony i zastany. U podstaw Nowej Humanistyki leży zatem nie oświecenie, lecz Heidegger ze swoją miażdżącą krytyką podmiotowości nowożytnej i jej $M a-$ chenschaft, czyli kalkulującej postawy wobec świata, z którym nie czuje się ona związana. Brak więzi oznacza tu także brak więzów: rozkiełznany podmiot kalkulującej racjonalności okazuje się źródłem nieograniczonej przemocy wobec bycia, która pozostaje wobec niego zewnętrzna. Nowa Humanistyka przeciwstawia się hybris tak pojętej podmiotowej wolności, usiłując znaleźć dla niej granice: przywiązać ją z powrotem do bytu, a tym samym uwiązać: usidlić i spętać. A następnie, w geście odwrotnym do prometejskiej hybris opisanej przez Hölderlina: pęta znów zamienić w więzy miłości². O ile więc podmiot nowoczesny zrywa miłosne więzy przynależności, by zaznać ostatecznych stopni swobody, nierzadko istotnie graniczącej z obłędem ${ }^{3}$ - o tyle podmiot postnowoczesny usilnie odkrywa w sobie momenty wiązania, by ukrócić szaleństwo wolności i powrócić do stanu ograniczenia i partycypacji. Innymi słowy, pragnie na nowo zaznać „błogosławieństwa granic”: wykonać nie pro/trans/gresywny ruch wyjścia, lecz regresywny ruch powrotny na warunkach skruszonego syna marnotrawnego - manewr, który Grecy tragiczni określali jako nostos, czyli "powrót do domu"4.

Dziedzictwo Heideggera jest dla Nowej Humanistyki decydujące i to ono determinuje kształt, w jakim występują jej dwaj pozostali prekursorzy: Rousseau i Marks. Jest to kształt jednoznacznie antynowoczesny: i Rousseau jako teoretyk romantycznej nostalgii, marzącej o wszelkiego rodzaju powrotach (do natury, do wspólnoty, do łona), i Marks jako krytyk formacji liberalno-kapitalistycznej służą tu za wielkich hamulcowych, którzy - zgodnie $\mathrm{z}$ aforyzmem Waltera Benjamina - pociągają za hamulec bezpieczeństwa w rozpędzonym pociągu nowoczesności ${ }^{5}$. Rousseau, ugięty w soczewce

2 Por. F. Hölderlin Ren, w przekładzie Antoniego Libery: „Kimże był ten, kto pierwszy / Zerwał więzy miłości i uczynił z nich pęta?". Wedle Hölderlina, pozostającego wówczas pod urokiem Rousseau, był nim Prometeusz, który jako pierwszy przeciwstawił się władzy naturalno-bosko-fatalnego porządku, co stało się aktem założycielskim cywilizacji.

3 Na temat związków myśli kartezjańskiej z obłędem por. zwłaszcza J. Derrida Cogito i historia szaleństwa, przeł. T. Komendant, "Literatura na Świecie" $1988 \mathrm{nr} 8$.

4 O konieczności „powrotu do domu” będącym jednocześnie powrotem do Grecji tragicznej Heidegger pisze nieustannie, najwyraziściej jednak we Wprowadzeniu do metafizyki, przeł. R. Marszałek, KR, Warszawa 2000.

5 Por. W. Benjamin O pojęciu historii, przeł. K. Krzemieniowa, w: Anioł historii. Eseje, szkice, fragmenty, Wydawnictwo Poznańskie, Poznań 1996. 
heideggeryzmu, dostarcza argumentów na rzecz zaniechania sztucznego eksperymentu denaturalizacji: w myśl neorousseanizmu człowiek ma na powrót odnaleźć swoje miejsce w naturalnej całości, z której wyrwał się mocą szkodliwej iluzji, i raz jeszcze odkryć uroki bezpośredniego uczestnictwa. Uczestnictwo - słowo-klucz posthumanistycznej strategii - ma zapewnić jednostce pierwotne umocowanie i przynależność, uprzednie wobec jej krytycznej refleksji, a tym samym nakładające na nią aprioryczne ograniczenie. Pozytywność pierwotnej partycypacji - w wielości zarówno naturalnej, jak i społecznej - ma zatem wyznaczyć granice negatywności, w której w modernitas rozkwitała niczym nieograniczona myśl krytyczna. Z kolei „zheideggeryzowany" Marks służy nade wszystko jako modyfikator języków emancypacyjnych. Jako krytyk liberalnej formuły wolności negatywnej dostarcza argumentów na rzecz emancypacji nie $o d$, lecz do: wolności pozytywnej, której uwieńczeniem jest pełna identyfikacja podmiotu z jego bytowym uwarunkowaniem, czyli rasą, klasą i płcią. Celem emancypacji nie jest więc triumf świadomości nad bytem (co jeszcze pobrzmiewa w ostatniej formule emancypacji oświeceniowej jako transgresji u Michela Foucaulta czy Judith Butler), lecz rozpoznanie i przepracowanie granic, za pomocą których byt - uprzednia faktyczność rasowo-klasowo-genderowego uwarunkowania - określa jednostkową świadomość. W sukurs tak zmodyfikowanej teorii emancypacyjnej idzie psychoanaliza, w której w późnej nowoczesności zachodzi analogiczna przemiana dyskursu. O ile bowiem Freud widzi jeszcze możliwość terapii jako wyzwolenia psychiki od traumy, która zaburzyła początki psychogenezy - o tyle Lacan zmienia sens terapeutycznego sukcesu, lokując go w pozytywnym przejęciu traumy jako warunku - kamienia węgielnego, na którym spoczywa cała konstrukcja podmiotowa.

Bez względu więc na to, jaki myśliciel znajdzie się w kręgu zainteresowania Nowej Humanistyki - czy będzie to Rousseau, Marks, Spinoza, Nietzsche czy Freud - zasada recepcji pozostaje heideggerowska z ducha: nowoczesna negatywność, która dała podmiotowi nieskończoną perspektywę krytyczną, zostaje spętana i ukrócona przez Nową Pozytywność, w której na plan pierwszy wysuwa się bezpośredniość uwarunkowania i partycypacji albo, innymi słowy, prymat faktyczności. Nowa Humanistyka jest zatem zdecydowanie antyheglowska: Marksowskie stawianie Hegla na nogi jest tu równoznaczne z procesem pętania myśli przez factum brutum materii. Nowy Materializm działa tu na zasadzie Goetheańskiej przestrogi: am Ende bist du, was du bist; „,w końcu jesteś tylko tym, czym jesteś". Nieograniczone stopnie swobody, w jakich porusza się wolna Heglowska myśl, okazują się sferą widmową: pozbawione realności 
stają się tylko epifenomenem - „pianą" - wytwarzaną przez myślenie, ten kwiat oderwany od swoich korzeni i zbuntowany przeciw nim.

Materialistyczny plan Nowej Humanistyki można nazwać, za Derridą, wielkim egzorcyzmem widm, którym odmawia się jakiejkolwiek wagi ${ }^{6}$. Jako nieważkie iluzje stają się one tylko przeszkodą na drodze pozytywnej identyfikacji ducha i materii czy raczej ostatecznej redukcji ducha do jego materialnych uwarunkowań. Materializm Nowej Humanistyki jest więc eliminatywny - i tylko w tym aspekcie można uznać ją za spadkobierczynię oświecenia, pojmowanego przede wszystkim jako odczarowanie. Egzorcyzm widm, którego celem jest eliminacja spektralnego wymiaru myślenia wykraczającego poza to, co jest, w stronę tego, czego jeszcze nie ma (Blochowskie noch-nicht), wpisuje się w ruch Entzauberung, które pozbawia myśl jej podstawowej prerogatywy - możliwości składania obietnic. Etyczna obietnica - ten najbardziej widmowy z aspektów ducha, wychylający się ku temu, co najmniej istniejące, najbardziej noch-nicht, czysto ideatyczne - musi bowiem rozwiać się pod naporem „tyranii faktów”. Oświecenie jako obietnica - obietnica powszechnej emancypacji i sprawiedliwości - znika na rzecz oświecenia jako samego tylko ruchu odczarowania. W tym też sensie jest Nowa Humanistyka spełnioną dialektyką oświecenia wedle Horkheimera i Adorno: spełnioną, rzecz jasna, w sensie pejoratywnym, czyli - unieruchomioną i zakończoną7.

\section{Posthumanizm jako konformizm}

Nie ulega wątpliwości, że w tym ukróceniu szaleństwa absolutnie swobodnej podmiotowości jest metoda. Hybris nowoczesności, bezgranicznie wierząca w widmo nieskończonego rozwoju, przynosi szkody nie tylko planecie, ale także ludzkim wspólnotom, na koniec również samej jednostce. Topos ponownego ograniczenia narzuca się więc myśleniu spontanicznie. Warto jednak zastanowić się, czy to poszukiwanie nowych granic musi przebiegać właśnie na sposób, jaki proponuje Nowa Humanistyka, mobilizując w tym celu wszystkie najpotężniejsze dyskursy antynowoczesne: heideggeryzm, nostalgiczno-ekologiczny rousseanizm oraz mniej lub bardziej redukcyjny marksizm (w tym właśnie nie-Marksowski, że pozostający w łonie

6 Por. J. Derrida Widma Marksa. Stan długu, praca żałoby i nowa Międzynarodówka, przeł. T. Załuski, PWN, Warszawa 2016.

7 Por. M. Horkheimer, T.W. Adorno Dialektyka oświecenia, przeł. M. Łukasiewicz, IFIS PAN, Warszawa 1997. Odtąd w tekście jako DO. 
romantycznej antimoderne). W rezultacie otrzymujemy bowiem mieszankę, która jest tyleż lekarstwem, co trucizną: ograniczenie podmiotowej wolności okazuje się w istocie rezygnacją z idei jednostkowego podmiotu w ogóle. Uwięziona w swej materialnej faktyczności - gatunku, rasie, klasie i płci subiektywność zanika na rzecz swego uwarunkowania.

Nowa Humanistyka stanowi więc skrajną reakcję na równie skrajną koncepcję podmiotowości: jej eliminatywny materializm opiera się na całkowitym odrzuceniu tradycji pneumatycznej, która - od czasów św. Pawła - determinuje najpierw duchowy kształt chrześcijaństwa, a następnie filozoficzną ideę podmiotu jako odciętego od wymiaru cielesnego. Jednakże, będąc tylko negacją tamtego porządku, Nowa Humanistyka ryzykuje wieczne uwikłanie w dualizm, który - w deklaracjach choćby - chciałaby przekroczyć. Tak jak Pawłowy pneumatyzm - wiara w cząstkę duszy nieśmiertelnej, chwilowo tylko wrzuconej w świat materialny - nadał pojęciu ducha postać radykalną i nazbyt wysublimowaną, tak też materializm Nowej Humanistyki całkowicie z idei ducha rezygnuje, tym samym podając w wątpliwość swój humanistyczny status, czyli właśnie ciąłłość z „naukami o duchu” (Geisteswissenschaften). Sięgając po zbyt prostą negację, Nowa Humanistyka przestaje być humanistyką; otwierając się na perspektywę posthumanistyczną, zaleca wręcz strategię dehumanizacji.

Posthumanistyka twierdzi przy tym, że w ten sposób dekonstruuje obłudę humanizmu, który w jej redukcyjnym neorousseańskim ujęciu sprowadza się tylko do uzasadnienia władzy martwego białego mężczyzny nad resztą świata, czyli do tzw. speciesm: „gatunkizmu”, gdzie jeden naturalny gatunek uzurpuje sobie prawo do dominacji nad innymi, wykorzystując w tym celu religijną ideologię (zgodnie z biblijnym zaleceniem: „czyńcie sobie ziemię poddaną").W posthumanistycznej perspektywie zawsze zatem byliśmy częścią przyrody i zawsze podlegaliśmy jej prawom, nawet jeśli humanizm głosił zasadę Oświecenia jako Wyjścia z domu niewoli wszelkich bezrefleksyjnych, pozornie naturalnych praw (vide Kant). We have never been human, głosi jedno $\mathrm{z}$ naczelnych haseł posthumanizmu, wypowiedziane przez Bruno Latoura: nigdy nie udał nam się żaden exodus ze świata natury, od zawsze byliśmy i na zawsze pozostaniemy tylko trybikiem w organicznym młynie życia i śmierci, do którego pozostaje nam się tylko przystosować ${ }^{8}$. Ta zasada naturalistycznego konformizmu stoi w rażącej sprzeczności z pryncypiami myślenia

8 Por. B. Latour Nigdy nie byliśmy nowocześni. Studium a antropologii symetrycznej, przeł. M. Gdula, Oficyna Naukowa, Warszawa 2011. 
krytycznego, które stało się możliwe tylko dzięki denaturalizacji, czyli wyjściu poza obszar obowiązywania przyrodniczego kryterium przeżycia.

Gdyby więc posthumanizm był prawdziwie konsekwentny, a nie tylko pasożytniczy w stosunku do myśli krytycznej, którą jednocześnie eksploatuje i podważa, to musiałby się wyrzec postawy krytycznej jako zdecydowanie nienaturalnej (tak też zresztą czyni Peter Sloterdijk, posthumanista nieobłudny, ale też niezbyt postępowy). W istocie bowiem posthumanizm współpracuje z najmroczniejszymi i najbardziej cynicznymi tendencjami naszej epoki: z jej odczarowanym, późnonowoczesnym realizmem, który jako swą poznawczą zdobycz przedstawia coś, co jeszcze dwa wieki temu uchodziłoby za błąd ontologiczny, czyli próbę wywiedzenia tego, co być powinno, z tego, co jest. Dziś do nikogo już prawie nie przemawia argumentacja Kanta, że Sollen (sfera powinności) nie tylko nie bierze się z Sein (sfery bytu), ale jest mu wręcz przeciwstawna, czyli, jak mawiał Steven Schwarzschild, współczesny żydowski kantysta: „Mieć etykę jest tym samym, co mieć alternatywę dla rzeczywistości"’. Otóż to właśnie radykalne rozumienie etycznej normy niewywodliwej z faktów i oferującej wobec nich alternatywną wizję życia - dziś ulega posthumanistycznej dekonstrukcji, która sprowadza je na powrót do odwiecznych relacji panowania, z jakich usiłowało wyjść. Zasada przyrodniczej rzeczywistości rządzi niepodzielnie, żądając, by nasze normy podporząadkowały się czemuś, co Adorno nazywał, wciąż jeszcze w poczuciu oporu, „hańbą adaptacji”10. To, co niegdyś uchodziło za normę normy - jej alternatywność wobec świata faktycznego - dziś uchodzi za utopistyczną patologię wyrażającą nieuprawnione roszczenia wobec społecznego bytu, który ,jest, jaki jest”. Wbrew więc szumnym deklaracjom radykalnej niezgody na polityczny zastany stan rzeczy posthumanista w istocie kolaboruje $\mathrm{z}$ biopolitycznymi ekspertami i ich znaturalizowaną wizją turbokapitalizmu: obie strony zgadzają się bowiem, że nigdy żadnego Wyjścia-z-Natury nie było. Postawa krytyczna jest tu tylko Sloterdijkowską "pianą" (Schaüme) - czyli biciem piany, po prostu"1.

9 S. Schwarzschild The Lure of Immanence, w: The Pursuit of the Ideal. Jewish Writings of Steven Schwarzschild, ed. by M. Keller, SUNY Press, Albany 1990, s. 73: „To have an ethics means to have an alternative to reality".

T.W. Adorno Minima moralia. Refleksje z poharatanego życia, przeł. M. Łukasiewicz, Wydawnictwo Literackie, Kraków 1999, s. 111.

11 Por. P. Sloterdijk Sphären. Plurale Sphärologie, Band 3: Shäume, Suhrkamp/ Insel, Frankfurt am Main 2004. 
Dlatego warto zadać sobie pytanie, czy nie można by pomyśleć nowych granic w naprawdę nowym języku, który nie oznaczałby całkowitego potępienia modernitas, a jedynie dialektyczne zniesienie jej najbardziej przemocowych momentów. W swoim eseju chciałabym zakreślić taką perspektywę: wyjście poza "rozum instrumentalny" nadal zgodne z podstawowymi przesłankami oświecenia, czyli bez uciekania się do jednoznacznie antynowoczesnej triady heideggeryzmu, neorousseanizmu i (źle pojętego) marksizmu.

\section{Mniej czy więcej człowieka?}

Posthumanizm jako regres do wspólnoty naturalnej - pojmowanej nawet tak szeroko i z pozoru bezdefinicyjnie, jak czyni to Latour - jest więc, po pierwsze, niemożliwy jako zabieg na człowieczeństwie, a po drugie, niepożądany jako postulat nadmiernie ograniczający krytyczne nastawienie ludzkiego podmiotu. Heideggerowska idea granicy ontologicznej, wyłożona w jego analityce skończoności, nie sprawdza się jako podłoże wizji przyszłościowej: jest raczej częścią symptomu niż jego rozwiązaniem. Choć więc panuje zgoda co do tego, że człowiek musi nauczyć się żyć na nowo w poczuciu granic, spór dotyczy tego, co ma go ograniczyć: naturalny kres w postaci śmierci, który dotyka każdy byt skończony zawarty w systemie kosmicznej natury - czy może prawdziwie ludzka, etyczno-krytyczna nowa granica, którą wyznacza Inny? Mocno skłaniam się ku temu drugiemu rozwiązaniu, które nie tylko pozostaje na gruncie humanistyki, ale jeszcze ją umacnia, ponieważ stawia na zasadę etycznego samoograniczenia, do której zdolny jest tylko i wyłącznie podmiot ludzki ${ }^{12}$.

Chcę przy tym podkreślić, że tak silnie zaakcentowany motyw różnicy antropologicznej wcale nie musi się automatycznie przekładać na różnicę statusu w ramach hierarchii metafizycznej. Różnica, na którą składa się cała seria subtelnych wyróżnicowań istoty ludzkiej z królestwa zwierzęcego - często bardziej ilościowych niż jakościowych - nie stanowi oczywistej podstawy do wartościowania: człowiek nie jest koroną stworzenia, czymś lepszym i wyższym niż reszta bytów. A jednak, ze względu na szczególną refleksyjną naturę swoich procesów poznawczych, które wyraża w języku, tylko człowiek - jak na razie - okazuje się zdolny do sformułowania idei prawa powszechnego, a następnie poddania się mu w geście samoograniczenia. Co nie znaczy, że proces ten nie odbywa się bez swoich patologii; te dogłębnie dekonstruuje Jacques Derrida w eseju Zwierzę, którym więc jestem (tytuł przekładam zgodnie z sugestią Michała Kozy), jednocześnie nie znosząc samej różnicy gatunkowej homo sapiens. Por. J. Derrida The Animal That Therefore I Am (More to Follow), trans. by D. Wills, Fordham University Press, New York 2008. 
Najbardziej wyrazistym eksponentem tego przeświadczenia jest Emmanuel Lévinas, który nie przypadkiem sformułował je w polemice z dziedzictwem Heideggera. Wskazując na wątpliwe atrakcje antyhumanizmu, którymi mami mitologiczny regres spod Heideggerowskiego znaku, Lévinas pisze w Trudnej wolności:

Ta doktryna jest subtelna i nowa. Wszystko, co, jak przez wieki nam się wydawało, zostało dodane do natury przez człowieka, tak naprawdę odsłania się w odwiecznych splendorach świata. Dzieło sztuki, przez które prześwieca samo Bycie, a nie ludzka inwencja, błyszczy nieludzkim światłem. Mit objawia się w naturze. Natura przemawia tym pierwszym mitycznym językiem, który funduje język ludzki. Człowiek musi więc słuchać i odpowiadać. Ale być posłusznym temu językowi znaczy odeprzeć pokusę logiki, która wyradza się w system wiedzy; znaczy żyć w danym nam miejscu, w byciu-tam. Zakorzenienie... Tyle że model roślinny nie wystarcza, by zdefiniować nasz stosunek do świata. Zbyt mało człowieczeństwa oddala nas od natury, lecz jeszcze więcej przybliża nas do niej na powrót. ${ }^{13}$

To ostatnie zdanie, które pojawiło się jako motto eseju, wyjaśnia istotę mojej propozycji: wbrew anty- i posthumanistycznym argumentom, które wyrosły w mitycznym cieniu Heideggera, sądzę, że uratować nas może nie zapowiadany przez Przyczynki nie-ludzki bóg, wyłoniony u kresu dziejów przez samo Bycie, lecz raczej hasło - więcej człowieczeństwa - realizowane w duchu etycznego przebudzenia.

W tym celu trzeba teraz zwrócić się do późnego Adorna, a zwłaszcza do jego koncepcji „pojednania z naturą”. W ostatnich debatach okołoekologicznych nazwisko Adorna prawie nigdy nie pada, ale jest to tylko błąd wynikający ze złego - nadmiernie Heideggerowskiego - ustawienia dyskursu. Jeśli bowiem Adorno się pojawia, to wyłącznie w negatywnym kontekście. Dla posthumanistycznych zwolenników ekologii głębokiej z ich nowym naturalizmem Adorno uosabia wręcz wrogi paradygmat antropocentrycznego modernizmu, który zdemonizował naturę i przeciwstawił ją ludzkiej kulturze. Z kolei dla postnaturalistów w rodzaju Bruno Latoura Adorno, wraz z innymi myślicielami nowoczesności, jest częścią wielkiej pomyłki, polegającej 
na hipostazie pojęcia natury ${ }^{14}$. Podczas więc gdy posthumanizm kontestuje antynaturalistyczną pozycję Adorna i proponuje w zamian przyłączenie człowieka do przyrodniczego ekosystemu, postnaturaliści odcinają się od wszystkich filozofii natury, bez względu na to, czy są one za naturą, czy przeciw - czy też, jak dzieje się w dialektycznym przypadku Adorna, będącego za i przeciw jednocześnie.

Komplikacja Adorniańskiego stanowiska wyraża się już w samym sloganie „pojednania z naturą”. Heglowski termin Versöhnung sugeruje, że nie ma tu mowy o prostym powrocie. O ile więc posthumanistyczna ekologia jest naznaczona pewną fantazmatyczną naiwnością, która projektuje życie naturalne jako doskonale funkcjonującą biologiczną maszynerię i przeciwstawia ją marnotrawstwu ludzkiej gospodarki, o tyle Adorno pozostaje wolny od jakiejkolwiek naturalistycznej nostalgii i zawartego w niej potępienia technologii. Powrót do natury jest niemożliwy - nie tylko dlatego, że nie ma do czego wracać (jak słusznie zauważają krytycy „,antropocenu”, nie istnieją już dziewicze ekosystemy nietknięte ludzką ręką), ale też dlatego, że nie byłby to słuszny ruch. Sam termin pojednania zakłada, że między ludzkim a przyrodniczym sposobem istnienia zachodzi różnica, której nie sposób wymazać, ale w łonie której można negocjować. Adorno jest więc silnym zwolennikiem tzw. „różnicy antropologicznej”, ale z równie zdecydowaną dialektyczną wariacją, dzięki której pełne ustanowienie różnicy między człowiekiem a przyrodą staje się koniecznym warunkiem wynegocjowania nowej relacji między nimi. Dokładnie zatem tak, jak w diagnozie Lévinasa: „mniej człowieczeństwa" utrzymuje stan wrogości między człowiekiem a naturą - „więcej człowieczeństwa" jednak sprawia, że człowiek stopniowo włącza byty naturalne w obszar swoich zainteresowań etycznych.

Często określa się dialektykę negatywną Adorna jako „skantyzowany heglizm" - i nie inaczej sprawa ma się z jego "pojednaniem z naturą". Hegel może istotnie nadejść dopiero po Kancie, czyli: istota ludzka musi najpierw odróżnić się od przyrodniczej totalności i dopiero później, już wolna od naturalistycznych kryteriów, ponownie ustanowić relację ze światem natury, ale wówczas już tylko w oparciu o swój własny zestaw wartości - w tym zwłaszcza kategorii sprawiedliwości. Kantowska krytyka przyrody jako Królestwa Konieczności, czyli opresyjnej formy życia nastawionego na proste przeżycie, oraz ugruntowanie moralności na antynaturalnych podstawach muszą więc 
poprzedzać Heglowski moment pojednania, który tylko dzięki temu może stać się aktem sprawiedliwości, czyli gestem etycznym niesprowadzalnym do zasad naturalnych. Inaczej, czyli bez kantowskiej antytezy, pojednanie sprowadzi się tylko do kapitulacji wobec przeważających sił natury: do konformistycznej uległości wobec jej biopolitycznych reguł gry, a więc do „hańby adaptacji". Wedle Adorna bowiem, który tu wiernie naśladuje Kanta ${ }^{15}$, natura jako taka nie zna sprawiedliwości; natura zna tylko pewien podstawowy rodzaj fairness, która wszystkich, bez wyboru i po równo, skazuje na ten sam los „powstawania i ginięcia”. Etyczna idea sprawiedliwości nie czerpie jednak z tak pojętego naturalistycznego egalitaryzmu, gdzie działa „wszystko zrównujące ramię fatum" (Nietzsche): czerpie z maksymy uważności wobec Innego, który - jako jednostka i byt odrębny - musi być zawsze traktowany jako cel sam w sobie, nigdy jako środek. Podczas więc gdy z punktu widzenia natury, jej egalitarna fairness polega na potraktowaniu każdego bez wyjątku tylko jako środka - środka do podtrzymania natury jako systemu - z punktu widzenia kantowskiego człowieka sprawiedliwość etyczna polega na wyrwaniu bytów poszczególnych z naturalnej machiny środków i uznaniu w nich celów samych w sobie. Exodus z natury, umożliwiony przez „różnicę antropologiczną”, jest tu więc tym samym, co przejście od Królestwa Środków do Królestwa Celów. Dopiero gdy człowiek opuszcza naturę - ten Schopenhauerowski młyn życia i śmierci, który przemiela każdą jednostkową egzystencję, by się nią pożywić - może w nim zakiełkować idea sprawiedliwości. I też tylko dopiero wtedy człowiek może ponownie zwrócić się do natury w duchu, który jej samej pozostaje radykalnie obcy, czyli objąć ją zakazem instrumentalizacji. Dopóki jednak w naturze pozostaje, dopóty ma naturalne przyzwolenie, by wszystkich i wszystko potraktować wyłącznie jako środek do własnych surwiwistycznych celów ${ }^{16}$.

15 Choć nie jest to kantyzm wolny od krytyki. W geście antycypującym obiekcje Lacana oraz dekonstrukcję Derridy Adorno stanowczo przeciwstawia się temu aspektowi Kantowskiej etyki, który w pełni sankcjonuje akt przemocowej negacji natury i odrzucenia jej jako "patologii". W rozdziale Dialektyki oświecenia poświęconym nowożytnemu podmiotowi Adorno zestawia Kanta z markizem de Sade (co później Lacan powtórzy w swoim „Kant avec Sade”), ukazując sadyczny element zawarty w kantowskiej antytezie. Jednocześnie będzie dialektycznie twierdził, że ten sadyczny etap gwałtownego wyróżnicowania jest nie do ominięcia: grunt jednak, by nie traktować go jako rozwiązania ostatecznego, lecz poszukiwać sposobu na zwrotne "pojednanie".

16 W tym kontekście warto zwrócić uwagę na zabieg Giorgio Agambena, który dobrze wpisuje się w posthumanistyczną strategię renaturalizacji człowieka, czyli m.in. "osłabiania” napięcia między sferą bytu a sferą powinności: rehabilitację idei środka. Idea ta, najpierw wyrażona w eseju o Benjaminie pt. Środki bez celu, a następnie rozwinięta w Użytku z ciał, uderza w radykalną 
Paradoksalnie zatem - ale tylko z pozoru i z początku - człowiek musi więc wyjść z natury, aby przestać zadawać jej gwałt. W świecie mitycznym nie ma bowiem sprawiedliwości, jest tylko twarde i okrutne prawo:
Świat, którym włada mana, a także świat hinduskiego i greckiego mitu są beznadziejne i wiecznie takie same. Każde narodziny okupione są śmier- cią, każde szczęście - nieszczęściem. Ludzie i bogowie mogą próbować w czasie, który został im dany, inaczej rozdzielić losy niż ślepy tok prze- znaczenia - na ostatku jednak zatriumfuje nad nimi istnienie. Nawet ich sprawiedliwość, wydarta fatalności, nosi jej rysy... Sprawiedliwość wyradza sięw prawo. (DO, 32; moja emfaza)

U Adorna zatem pierwszym mitycznym więzieniem pojedynczego życia jest właśnie natura; wszelkie formy kulturowe, przybierające postać „mityczną” czyli „wyrzekającą się nadziei” - jedynie imitują cykliczną równowagę świata

koncepcję działania etycznego opartego na zakazie instrumentalizacji oraz trosce o nienaruszalność innego jako celu samego w sobie. Zarówno zakaz użytkowania, jak troska o nienaruszalność tego, co inne, wydają się Agambenowi niepotrzebnie wygórowaną stawką etyki, która powinna móc obyć się bez inwestycji w osobność człowieczeństwa. Zdaniem Agambena sedno problemu tkwi nie w użytku jako takim, lecz w użytku, który przez nadmiar posesywności staje się nadużyciem: rzymski jus utendi et abutendi wystarcza, by wykreślić jasne granice tego pierwszego. W istocie więc to człowiek, który, jak twierdził już Jean-Jacques Rousseau, wymyślił prawo własności, okazuje się tym, którym nadużywa prawa użycia w świecie natury - inaczej niż zwierzę, które używa świata i siebie niewinnie, nie biorąc nic w posiadanie. Nie chodzi więc o to, by się o siebie i innych troszczyć - humanistyczny paradygmat troski powinien zostać przezwyciężony - ale o to, by niewinnie używać: korzystać z ciał, swoich i własnych, do woli, aż do momentu ich „nienaprawialnego" zepsucia, które należy wówczas potraktować jako naturalną kolej rzeczy, tak jak czyni to zwierzę, zawsze at ease wobec losu, jaki dyktuje mu porządek naturalny. Nie ma więc nic złego w samej instrumentalizacji, którą posługuje się natura; to tylko człowiek, nadużywając zasady środka - jako środka do celu, którym jest przywłaszczenie - wypacza Królestwo Środków i, zgodnie a nauczaniem neorousseanizmu, zasługuje na likwidację. Lekcja Agambena doskonale unaocznia, że posthumanistyczny neorousseanizm jest stanowiskiem całkowicie niewywrotnym, którego podstawową zasadą jest: jeśli gdzieś dzieje się źle, winien jest człowiek. Jeżeli więc natura jawi nam się jako domena darwinowskiego survival of the fittest i Hobbesowskiej bella omnium contra omnes, to tylko dlatego, że człowiek dokonuje tu projekcji swojej własnej podmiotowej patologii: w istocie, gdyby zdystansować się od tych projekcji, natura okazałaby swoje niewinne oblicze. Gdyby spojrzeć na neorousseanizm w teologicznej perspektywie, byłaby to najbardziej skrajna i ledwo co zsekularyzowana forma augustyńskiej teodycei, w której człowiek, nosiciel grzechu pierworodnego, odpowiada za wszelkie zło. Por. G. Agamben Means without Ends: Notes on Politics, trans. by V. Binetti, Minnesota University Press, Minneapolis 2000, a także The Use of Bodies, trans. by A. Kotsko, Stanford University Press, Stanford 2015. 
naturalnego". Podporządkowanie naturze oznacza bowiem elementarne zniewolenie: posłuszeństwo wobec prawa nieubłaganego cyklu, rządzonego zasadą fatalistycznej przemienności hybris i nemesis, pychy i zemsty, zgodnie z którą wszystko, co zaistniało, musi zostać ukarane za iluzję jednostkowości i na powrót sprowadzone do roli środka. Tak długo, jak człowiek pozostaje we władzy tego najbardziej fundamentalnego z naturalnych praw, oświecenie pozostanie tylko kontynuacją natury - dosłownie - innymi środkami; będzie tylko kolejną formą mściwej dominacji ogólności nad poszczególnością. $\mathrm{Na}$ tym właśnie polega Adornowska dialektyka oświecenia; dopóki człowiek nie opuści natury naprawdę, dopóty będzie jedynie powtarzał jej schemat „mściwej konieczności" w ramach pozornego wyzwolenia, które oznacza jedynie odwrócenie relacji panowania -

Ale w miarę jak magiczne złudzenie [wolności - A.B.-R.)] się rozwiewa, tym bezwzględniej powtórzenie - pod nazwą prawidłowości - więzi człowieka w owym cyklu, choć uprzedmiotawiając go w prawie przyrody człowiek sobie roi, iż tym samym ma zapewnioną pozycję wolnego podmiotu. Zasada immanencji, uznania każdego wydarzenia za powtórzenie, którą to zasadę oświecenie reprezentuje przeciwko wyobraźni mitycznej, jest zasadą samego mitu. Sucha mądrość, która nie dopuszcza niczego nowego pod słońcem, albowiem wszystkie karty bezsensownej gry jakoby zostały już zgrane, wszystkie wielkie myśli już pomyślane, możliwe wynalazki z góry już wykalkulowane, a ludzie skazani na samozachowanie przez adaptację - owa sucha mądrość reprodukuje jedynie mądrość fantastyczną, którą sama odrzuca: sankcję losu, który przez zemstę nieustannie wytwarza to, co już było.To, co byłoby inne, zostaje ujednolicone. Oto werdykt, który krytycznie ustanawia granice możliwego doświadczenia. Wszystko tożsame jest ze wszystkim ale za to nic już nie może być tożsame z samym sobą. (DO, 28)

Ani u Kanta, ani u Lévinasa, ani też u Adorna idea Wyjścia z Natury nie pojawia się przypadkiem. U tych trzech wielkich myślicieli, którym wciąż przyświeca ideał etycznej obietnicy, biblijna opowieść o jeciat micraim,

17 W Dialektyce oświecenia Adorno i Horkheimer definiują mit jako figurę wiecznego cyklu i powrotu (Kreislauf), która staje się także nadrzędną figurą oświecenia w chwili, gdy to zaczyna poddawać się "prawom naturalnym”: „Tym samym oświecenie popada z powrotem w mitologię, z której nigdy nie zdołało się wyrwać. Albowiem mitologia w swych figurach odzwierciedlała esencję tego, co trwale istnieje - wiecznie nawracający cykl, los, panowanie - jako prawdę i wyrzekała się nadziei" (DO, 43). 
exodusie z domu niewoli, stanowi solidną kanwę ich dialektycznej narracji o oświeceniu. Jej pierwszą fazą jest wyjście z niewoli naturalnej; drugą etap okrutnej walki z naturą o przeżycie, czyli wciąż na prawach przez nią dyktowanych; trzecią zaś realizacja obietnicy ukrytej w symbolu Exodusu, czyli prawdziwe wyjście z natury, w którym człowiek ostatecznie wyzwala się $\mathrm{z}$ naturalnych kryteriów surwiwalu. To prawdziwe wyzwolenie oznacza, że ludzki podmiot nie dokonuje już zwrotnej instrumentalizacji świata naturalnego, w której jedynie odwraca bieguny relacji panowania (zgodnie z zasadą mściwej retrybucji: „kiedyś natura rządziła nami, my dziś rządzimy nią”), lecz przyjmuje wobec bytów naturalnych nie-naturalną postawę etyczną: wykracza poza gry dominacji i przemocy, by zamieszkać w prawdziwie powszechnym Królestwie Celów.

\section{Pojednanie i jego dialektyka}

Myśl Adorna układa się więc w pewną heglowską triadę, o której najdokładniej opowiada Dialektyka oświecenia, biorąc za swą kanwę historię o Odyseuszu, czyli „mit o wyjściu z mityczności”, na którą następnie nakłada hebrajski motyw Eksodusu. Etap pierwszy to życie naturalne, symbolizowane przez senną krainę Lotofagów, w której proste szczęście bezpośredniego bytowania okupione jest miękką niewolą w służbie Matki Natury. Drugi etap to wyjście ze świata naturalnej niewoli, o niebezpieczeństwach którego tratuje przypowieść o Syrenach: żeglując przez heteryczne wody, Odyseusz wychodzi nietknięty przez syrenie pokusy, jednocześnie jednak „traci życie”. Uzyskując panowanie nad żywiołem, ustanawia podmiotowość ascetycznym gestem odcięcia się od zmysłowej rozkoszy. Staje się oświeconym podmiotem, panem swej świadomej egzystencji, tyle że kosztem tej relacji panowania okazuje się utrata witalności; opuściwszy zatokę Syren, Odyseusz wypływa na szerokie wody wolności od natury, gdzie, mimo całej tej nowo uzyskanej swobody, grozi mu bezkierunkowy dryf. Jest wprawdzie świadomością, skupioną na swoim samozachowaniu - kontroli impulsów naturalnych w sobie i poza sobą - ale jego ciało jest martwe: uprzedmiotowione i zdenaturalizowane.

Pierwsze wyjście z natury zatem, inicjujące w wymiar racjonalności i refleksyjności, okazuje się więc jednoznaczne z zabiciem natury w sobie - z poświęceniem siebie jako ofiarnego zwierzęcia:

Każda próba złamania przymusu natury, polegająca na złamaniu natury, powoduje tym większą zależność od przymusu natury. Tak przebiegała 
droga europejskiej cywilizacji. Abstrakcja, narzędzie oświecenia, odnosi się do swych przedmiotów niczym los, którego pojęcie chce wyeliminować: jako likwidator. (DO, 29)

Ażeby wyjść z impasu złego wyjścia z natury, Adorno proponuje spojrzeć na proces wyłaniania się podmiotowości nieco inaczej, w terminach innego, bardziej substancjalnego a mniej instrumentalnego, oświecenia - co inaugurować ma trzeci, najbardziej upragniony etap podmiotowego rozwoju. Narodziny rozumu bowiem to nie tylko odczarowanie pierwotnej tajemnicy i przejście do pozbawionych sakralnych lęków, cynicznych stosunków panowania; to także, a może przede wszystkim, narodziny sprawiedliwości. Narodziny żądania obcego naturze i wszelkiemu mitowi, który w swej pseudomądrości naśladuje cykliczny ruch physis i „tym samym wyrzeka się nadziei”.

Dialektyka oświecenia polega wówczas na kolizji dwóch modeli wyjścia z natury. Jeden, zawarty w figurze Odyseusza, stawia na czysto instrumentalną technikę odwracania relacji władzy, nie zmienia jednak nic w szerszym planie etycznym, wciąż pozostając w zasięgu oddziaływania mitu. Drugi natomiast, zawarty w figurze Exodusu, utożsamia wyjście z natury z narodzinami postawy moralnej, lecz w związku z tym natychmiast popada w potężny paradoks. Po jednej stronie bowiem mamy realną praktykę oświeceniową, polegającą na coraz głębszym odczarowywaniu natury, nad którą podmiot usiłuje utrzymać władzę tak długo, jak tylko się da - po drugiej zaś idealną etyczną formułę oświecenia jako żądania sprawiedliwości, która tym samym nie może uzasadnić gwałtu, jaki musi dokonać na naturze, by się z niej wyzwolić. Po jednej stronie zatem mamy czystą technikę oświecenia, które tylko pragnie panować nad naturą - po drugiej zaś czystą obietnicę, która w praktyce pozostaje sparaliżowana przez etyczny paradoks.

Rozwikłać ten paradoks oznacza „obronić oświecenie przed nim samym": wyrwać je z aporii sprawnego instrumentalizmu i bezczynnej obietnicy. Oznacza - uruchomić proces pojednania:

Oświecenie bowiem... które nie zachowuje w autorefleksji swojego związku z naturą, odcinając się od niej w wolności, staje się winą wobec natury, częścią mitycznego w nią uwikłania... Pojednanie nie jest prosta antyteza mitu, lecz winno mu nadto oddać sprawiedliwość. ${ }^{18}$

18 T.W. Adorno O literaturze. Wybór esejów, przeł. A. Wołkowicz, Czytelnik, Warszawa 2005, s. 256; moja emfaza. Odtąd jako OL. 
Pojednanie zatem to skomplikowany gest. Nie jest prostą antytezą mitu, czyli nie oznacza jego całkowitego potępienia: uznaje, że pierwsze wyjście z natury nie mogło odbyć się inaczej niż za sprawą mitycznej imitacji natury. Zarazem jednak rozszerza imperatyw sprawiedliwości na świat naturalny, który dotąd był zeń wykluczony. Adorno projektuje więc nowe kantowskie królestwo celów, gdzie pojedyncze życie - także to naturalne - ma prawo rozkwitnąć poza groźbą wszelkiej reifikacji: życie wolne od relacji władzy i przemocy, uwolnione do różnicy, czyli, jak mówi Adorno - „nietożsamości”. Adorno nie ukrywa, że inspiracją dla tej wizji nominalistycznego królestwa jest teologia mesjańska, która przeciwstawia się ujmowaniu świata w kategoriach ogólnych i powtarzalnych:

Świat jest wydarzeniem jednorazowym. Proste powtarzanie momentów, które nawracają wciąż w tej samej postaci, przypomina raczej daremną i kompulsywną litanię niż stowo zbawienia. (DO, 243; moja emfaza)

To w tej spełnionej jednorazowości realizuje się „zanikanie porządku naturalnego w innym porządku” (OL, 38), czyli w „dobrej ogólności wszystkiego, co żyje" (OL, 61), niedomykającej się już w naturalny system dominacji, która wymazuje wszelką pojedynczość. Natury nie można wprawdzie zbawić, ale można wykonać wobec niej mesjański gest polegający na etycznej rezygnacji z gwałtu i panowania: jakby powiedział Hegel, pozwolić jej żyć, „puścić ją wolno" (freilassen). Wówczas "pojednanie z naturą" znaczy tyle samo, co oddać sprawiedliwość temu, co samo nie zna sprawiedliwości; co samo w sobie „nie jest ani dobre, ani szlachetne" (DO, 56), ale co jako takie w żaden sposób nie usprawiedliwia popełnionego na nim gwałtu. Ofiara wcale nie musi być piękna, by budzić uzasadnione moralne współczucie.

Nie znaczy to więc, że na etapie pojednania człowiek będzie się domagać od natury, by ta przestała być naturą i przyjęła etyczne kryteria koegzystencji - czyli by, jak w apokaliptycznym obrazie przyszłego raju, łania mogła zlec obok wilka, zażywając mesjańskiego „wiecznego pokoju”. Adornowska idea pojednania z naturą jest wolna także i od tej formy przemocy, czyli przemocy etycznej konwersji - Augustyńskiego compelle intrare! - przymuszającej byty naturalne do wejścia w obręb Królestwa Celów. To raczej idea relacji świadomie asymetrycznej - tym razem zgodnie z Lévinasowską intuicją, że tylko radykalna asymetria decyduje o realnej etyczności, a nie pragmatyczna zasada wymiany do ut des. W ramach tej asymetrii człowiek uznaje naturę w jej nieprzekraczalnej różnicy: nie żąda, by istoty naturalne były zdolne do etycznej 
wzajemności. Ale jednocześnie unika pokusy renaturalizacji, powrotu na łono natury, stawiania się z nią jednym ${ }^{19}$. W schemacie Adorna człowiek późnonowoczesny powinien móc uderzyć się w pierś z powodu przemocy, jaką wyrządził był światu przyrody - a zarazem nie pomylić skruchy z dezawuacją. Podobnie bowiem jak niemowlę w psychoanalizie Melanie Klein, które chce stać się osobnym podmiotem, on także musi uznać gwałtowną fazę separacji za konieczną w procesie emancypacyjnym, gdzie w roli macierzyńskiego ciała występuje Matka Natura. Faza separacji, choć pełna mściwej przemocy, jest tu niezbędna, by wyemancypowana istota ludzka wypracowała odrębny kod etyczny, którego ostatnim nakazem okaże się - imperatyw pojednania ${ }^{20}$.

\section{***}

Nie w tym rzecz zatem, by człowieczeństwo ukarać i ukrócić, tak jakby chciał to uczynić posthumanizm, inspirowany tragicznymi naukami późnego Heideggera; wedle greckiej tragedii tak właśnie od zawsze działał system natury, zsyłając Erynie na każdego śmiałka z nadmiarem nieograniczonej hybris. Tak też zresztą działała dotąd ludzka cywilizacja, jedynie imitując przemoc naturalną w dominacyjnej relacji z naturą; cywilizacja, którą dziś myśl posthumanistyczna neguje z tą samą mściwą gwałtownością, z jaką ona wcześniej negowała samoistny świat przyrody. W tym też sensie Nowa Humanistyka

19 Tylko zresztą przy tej przesłance dodatkowej, jaką jest etyczna zasada asymetrii, idea „pojednania z naturą" przestaje być kwadraturą koła. Bez wprowadzenia tego entymematu rozważania Adorna wydają się uwikłane w beznadziejną "ambiwalencję pojęcia natury”, która wielu z jego krytyków doprowadza do rozpaczy. Jeden z nich, Steven Vogel, który poświęcił książkę problemowi natury w Szkole Frankfurckiej, definiuje jej "mętny” status tymi słowy: „Natura wydaje się być zarazem promesse de bonheur i obiektem największego lęku; czymś, co podlega niszczącej dominacji oświecenia, a jednocześnie czymś, co mści się straszliwie, kiedy dominacja ta (jak zawsze zresztą) zawodzi"; S. Vogel Against Nature. The Concept of Nature in Critical Theory, SUNY Press, Albany NY 1996, s. 84. I istotnie z rozpaczy chyba imputuje on Adorno "niejasne i nieprzekonujące tęsknoty animistyczne" (tamże, s. 3). Tymczasem dwuznaczność ta rozwiązuje się, jeśli przyjąć - jak najdalszą od wszelkich pogańskich animizmów - hebrajską wersję oświecenia jako przede wszystkim obietnicy sprawiedliwości.

Skojarzenie z Melanie Klein nie jest tu przypadkowe. W istocie można by zinterpretować Adornowski trzeci dialektyczny etap pojednania jako proces reparacji, który inicjuje w psychice poczucie winy wywołane jej zbyt gwałtownym zrywaniem pęt zależności. Nie chodzi więc o to, by człowiek - i reprezentujący go humanizm - w ogóle nie czuli się winni, a jedynie o to, by winę tę dobrze zdefiniować i ulokować, bez jej hiperbolicznego uogólnienia, jakie staje się udziałem: najpierw teodycei Augustyna, a następnie jej zeświecczonej wersji w postaci neorousseańskiej. 
znalazła się w impasie bez Wyjścia: w mitycznym kręgu (Kreislauf) gwałtu i retrybucji, który „wyrzeka się nadziei” - tej jedynej prawdziwej nadziei, która nie obiecuje już zemsty, lecz wykracza poza złą symetrię wiecznej przemocy. Tymczasem Adorno, wierny obietnicy Wyjścia, kreśli wizję, w której pojednanie z naturą to etyczny gest samoograniczenia - możliwy tylko wtedy, gdy człowiek stanie się nie mniej, lecz bardziej człowiekiem niż dotychczas.

\section{Abstract}

\section{Agata Bielik-Robson}

INSTITUTE OF PHILOSOPHY AND SOCIOLOGY OF THE POLISH ACADEMY OF SCIENCES, UNIVERSITY OF NOTTINGHAM

New Humanities: Looking for Limits

Bielik-Robson proposes a critical analysis of the New Humanities. Despite the seeming continuity of emancipatory approaches, she argues, the New Humanities are not founded on enlightenment philosophy but on Heidegger and his unconditional critique of modern subjectivity and its Machenschaft, i.e. its calculating attitude to the world, to which it does not feel connected. The lack of connection also signifies a lack of ties: the unbridled subject of calculating rationality turns out to be the source of unlimited violence towards being. The New Humanities oppose the hubris of such a notion of subjective freedom by trying to identify its limits: to link it with existence once again, and in this way to tie it up, to entrap and tether it. The goal is to experience the 'blessing of limits': not to make a progressive or transgressive move towards the exit, but to make a regressive move, somewhat like the prodigal son - a manoeuvre that the tragic Greeks described as nostos or'return home'.

\section{Keywords}

New Humanities, posthumanism, counter-enlightenment, dialectics of the enlightenment, Martin Heidegger, Theodor Adorno, Max Horkheimer, Emmanuel Levinas 